\title{
Post-Glacial Forest at Kayville Uncovered
}

By Joyce Dew, Saskatchewan Museum of Natural History

In October, 1958, evidence of a post-glacial forest was unearthed on Jack Scrimbit's farm at Kayville, Saskatchewan. Kayville lies in a rolling prairie region not far from Avonlea. In the area are many circular depressicns and knolls comprising knob and kettle topography of glacial origin, formed as a result of the melting away of blocks of ice buried in glacial till. Since most of these depressions have no outlet they filled with sediments, hence the many sloughs in the area today.

One of the shallow depressions on the Scrimbit farm was selected as the site of a dugout. The contractors, the Watson brothers of Avonlea, while excavating at a depth of 12 feet, found a $\log$ a foot in diameter which was as fresh in appearance as if it had only recently fallen into the mud. This was the discovery which brought Bruce McCorquodale and Albert Swanston from the Saskatche-

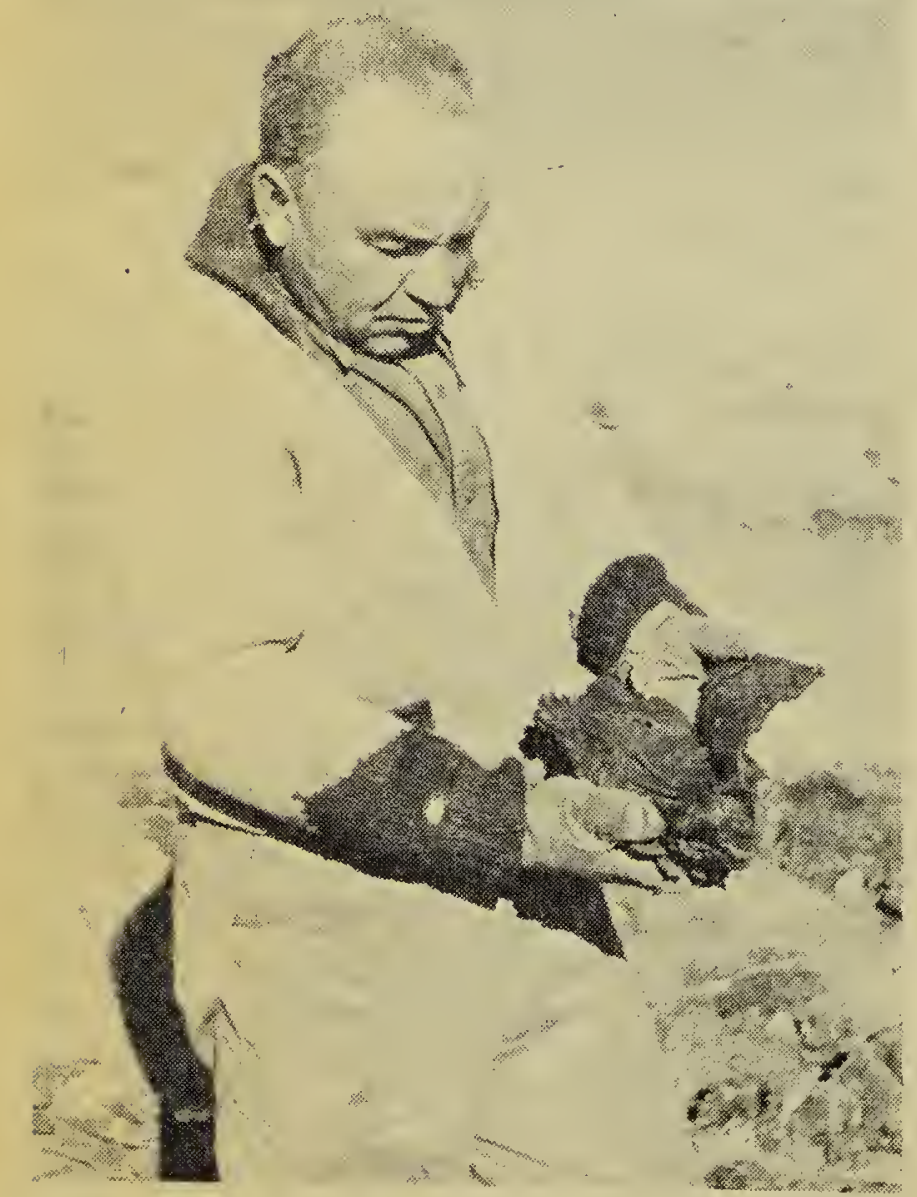

Photo by R. W. Fyfe

MR. JACK SCRIMBI'T PEELING LAYERS OFF A CHUNK OF GYTTJA FROM THE wan Museum of Natural Hisitory to investigate. They spent several weeks in the area and halted operations only when the onset of winter made it necessary. Much material was collected and brought back to the Museum for further study. Samples have been sent as well to scientists in other museums.

The log and other specimens were found in a layer of gyttja, pronounced "gea-cha" (a clay-like material composed of a high percentage of organic materials). This gyttja was in a bed over 8 feet thick and 12 feet below the surface. The gyttja when first uncovered gives off a strong odor resembling hydrogen sulphide, is rubbery in texture, grey-black in appearance and may be peeled off in layers. Embedded in the layers and pressed between them are almost perfectly preserved plants and animals. Pond weeds, moss and grass retain their natural color; there has

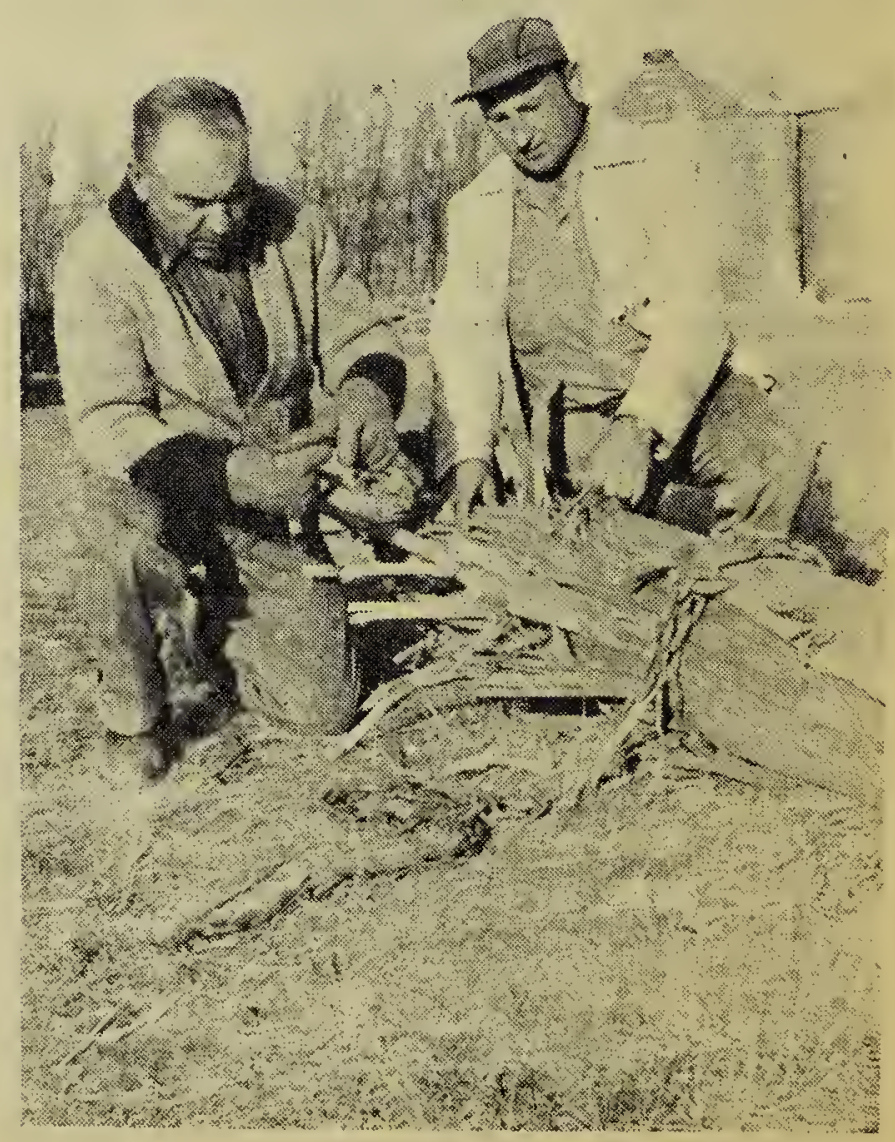

Photo by R. W. Fyfe

MR, SCRIMBIT AND SON, GORDON, EXAMINING ONE OF THE LOGS DISCOVERED AT THE SITE. 


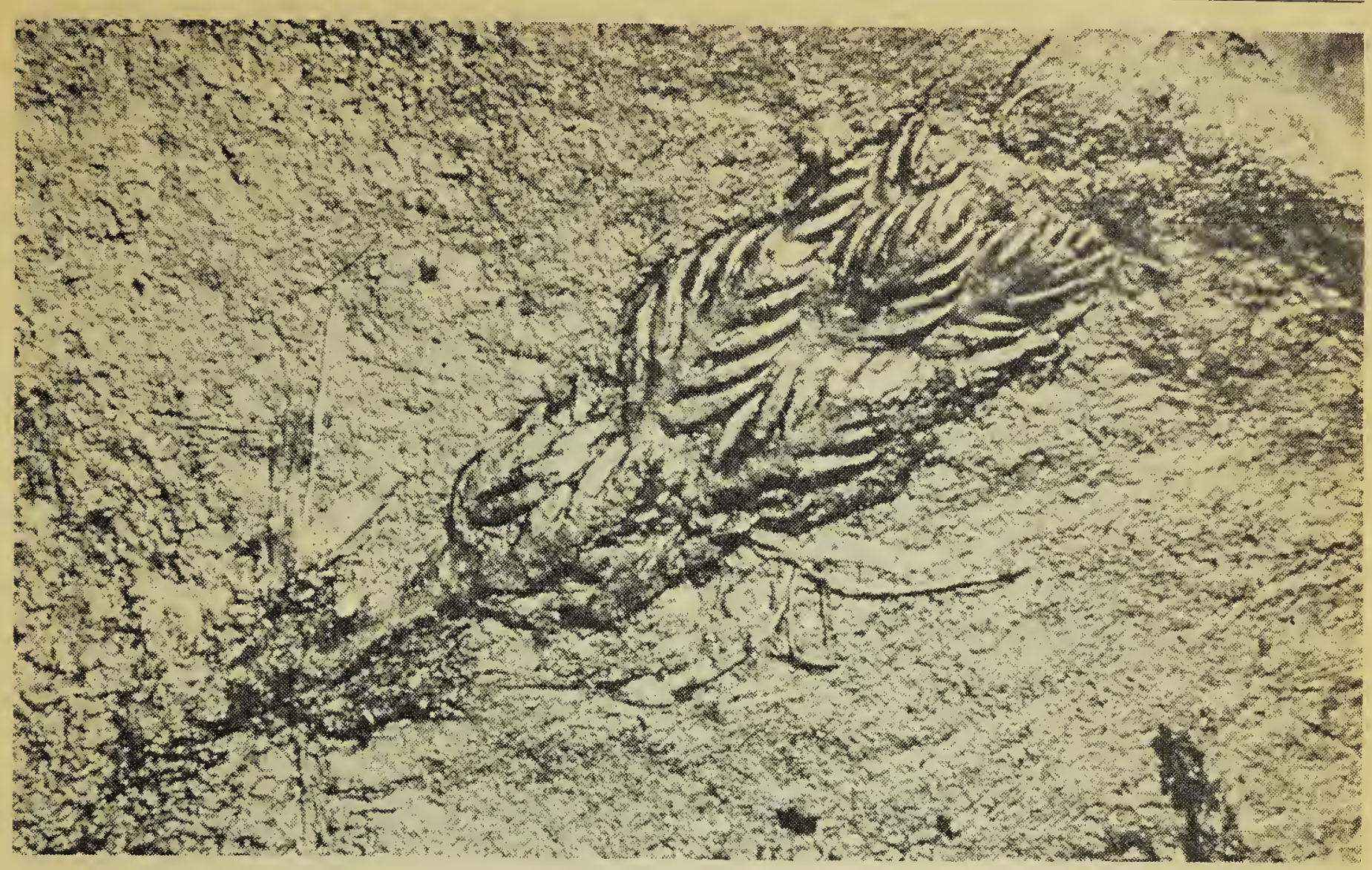

\section{Photo by R. W. Fyfe}

CLOSE-UP OF PONDWEED IN GYTTJA FROM THE SCRIMBIT FARIM.

been little decay and no fossilization has taken place. Insects are found pressed between the layers with fragile wing parts still intact. Snail shells, cones and needles of conifercus trees, and manure of planteating mammals are plentiful in the site. The skeleton of a rabbit, a log chewed by a beaver, and the egg of a bird are evidences of vertebrate life.

What is the significance of this find? We are now awaiting the Carbon-14 dating and the pollen analysis which will tell us the age of the site and of the vegetation which grew there. In the meantime it is thought that the site is of post-glacial origin anywhere from 5,000 to 12,000 years old. Relatively little is known of plant and animal life as it became re-established after the retreat of the glacier, and this find may tell us much. The carbon dating will enable us to place this site in its proper geological sequence. From the pollen analysis we shall know what plants grew at that time. Since the gyttja is deposited in well defined layers it will be possible to determine the succession of plant growth which occurred there. This in turn may reveal the climatic cycles of wet and dry years on the prairies and might provide a clue for forecasting future cycles.
There was a somewhat similar find in 1940 in a peat bog near Herbert, Saskatchewan. The material there was preserved in peat and was carbonated at $10,050 \pm 300$ years. Spruce cones, moss, seeds of a pondweed, snails and bark of a conifer were found there. Materials from both these sites are at present on display at the Museum.

Following the announcement of the discovery in the local press, over radio and TV, more reports have come to the Museum about twigs and branches found in wells and cther excavations in the district. These reports will be investigated and it is hoped thait readers who have knowledge of similar sites will write to the Museum.

\section{PINK SASKATOONS}

By LAD MARTINOVSKY, Gerald, Sask.

In July 1958 while picking saskatoons we came upon a row of pink coloured anes growing along a fence at the side of the road. Frcm the car as we drove along they appeared to us like some flowering shrub. IVhen we examined them more closely we discovered that they were really pink saskatoons. All tho other saskatoon fruits in the area were dark in colour. We picked a gallon of these berries, canning half of them and putting the rest in the deep freeze.

Last fall we dug up a number of roots which we buried for the winter and will plan't next spring. I have heard of white saskatoons being found. Would a person who has white saskatoons like to exchange some roots for the pink variety? 